\title{
CHEMICAL CHARACTERIZATION OF LIGNANS FROM Araucaria araucana A NATIVE CONIFER OF CHILE AND EVALUATION OF THEIR CYTOTOXICITY AND ANTIOXIDANT ACTIVITIES
}

\author{
GASTÓN BRAVO-ARREPOL ${ }^{a}$, SOLANGE TORRES ${ }^{a}$, FABIAN FIGUEROA $^{a}$, CLAUDIA PÉREZ $^{a, d}$, \\ CRISTIAN PAZ ${ }^{b}$, GIOVANNI TURCHETTI ${ }^{c}$, ANTONIO TIEZZI ${ }^{c}$ AND JOSÉ BECERRA ${ }^{a, d^{*}}$ \\ ${ }^{a}$ Departamento de Botánica, Facultad de Ciencias Naturales y Oceanográficas, Universidad de Concepción, Concepción, Chile. \\ ${ }^{b}$ Departamento de Ciencias Básicas, Universidad de La Frontera, Chile. \\ ${ }^{c}$ Dipartimento per la Innovazione nei Sistemi Biologici Agroalimentari e Forestali (DIBAF), Università degli Studi della Tuscia, Viterbo, Italy. \\ ${ }^{d}$ Universidad de Concepción, Unidad de Desarrollo Tecnológico (UDT).
}

\begin{abstract}
Araucaria araucana is a native conifer of Chile commonly called Araucaria. The knots of Araucaria are extremely hard wood and highly rot-resistant, they can be found in the forest decades after that the tree has dead and decomposed. Here we report the phytochemical characterization of different parts of the Araucaria as stemwood, branch and knots, founding a remarkable difference in the content of extractables in these parts, as well as the lignan composition, which is higher in knots than in branches or stemwood. Eudesmin was isolated and crystallized from organic extract of knots, its structure was determinate by NMR; moreover, secoisolariciresinol, lariciresinol and matairesinol were identified by GCMS and HPLC in contrast to standards, and quantified in stemwood, branch and knots. The results showed that secoisolariciresinol is the main lignan with $45.77 \mathrm{mg} \mathrm{g}^{-1}$, followed by eudesmin with $22.68 \mathrm{mg} \mathrm{g}^{-1}$, lariciresinol $4.57 \mathrm{mg} \mathrm{g}^{-1}$ and matairesinol with $1.19 \mathrm{mg} \mathrm{g}^{-1}$. The antioxidant activity in terms of DPPH assay showed that knotwood extract displays the higher activity, meanwhile that eudesmin did not displays activity in DPPH assay. The cytotoxic activity against SHSY5Y neuroblastoma and P3X myeloma cell lines, revelated a moderate activity of extracts, while eudesmin did not showed activity.
\end{abstract}

Keywords: Araucaria araucana, lignan, eudesmin, DPPH activity, cytotoxic activity.

\section{INTRODUCTION}

Lignans are a family of natural compounds formed by stereospecific coupling $\beta-\beta$ ' of two phenylpropane units $\left(\mathrm{C}_{6} \mathrm{C}_{3}\right)$ with a wide range of rearrangements, different oxidation degree, and condensations, emerging a broad type of compounds [1]. Lignans have been studied for their potential medicinal uses as phytohormone, treatment or prevention of various types of cancer, and neuroprotective effects, among others. They have been isolated from almost all vascular plants. However, their role in nature is not fully known. It has been suggested that they are part of the defense and resistance of conifers against pathogen attack $[2,3]$. In conifers, the extractable give protection from predators [4], and their concentration depends on the specie of tree, age, geographical location, stress, and different parts of the same tree. In fact, in hardwood as knots, extractable accumulate in higher concentration than in the heartwood, even up to 6 folds, with a concentration of lignans than exceed $10 \% \mathrm{w} / \mathrm{w}$. While, in coniferous species such as: Abies alba, Picea abies and Pinus sylvestris the concentration of lignans in knots can up to 200-folds [5, 6]. In Pinus sylvestris L., the extracts obtained from knots have showed a greater protective effect against brown rot fungus attack than extracts obtained from heartwood, also pointing to a direct relationship with the antioxidant capacity and components of extractable [7].

In Chile, Araucaria araucana, commonly called Araucaria, grow up over 2000 $\mathrm{m}$ in the center south of the country, and their knots are commonly known as "picoyo". They are an extremely hard wood and highly rot-resistant material, that has become used by artisans who collect them from degraded A. araucana trees to produce beautiful pieces of silverware. The picoyos of Araucaria can endure in the forest for many years without fungal attack, probably due to a high concentration of extractables[8-10], moreover for this reason, they were used as fuel for firewood with high calorific value. Knots of the Brazilian conifer $A$. angustifolia have a high presence of lignans, such as eudesmin, secoisolariciresinol and lariciresinol, but knots of Araucaria have not been chemically characterized in depth. The present study reports the chemical profile of heartwood, branches, and knots of A. araucana and their antioxidant and cytotoxic activity.

\section{EXPERIMENTAL}

\section{General Information}

Preparative chromatography was performed using Merck silica gel 60 (25-100 $\mu \mathrm{m}$; Aldrich, Santiago, Chile). Analytical thin-layer chromatography (TLC) was carried out on Merck silica gel 60F254 sheets (Darmstadt, Germany), eluted with $\mathrm{EtOH} /$ dichloromethane 7\% v/v and revelated with sulfuric acid EtOH 5\%, then eating at $150{ }^{\circ} \mathrm{C}$. Solvents as HPLC-grade water, acetonitrile, ethanol, acetone, formic acid, were obtained from Merck (Darmstadt, Germany). Lignan standards of pinoresinol, matairesinol, lariciresinol and secoisolariciresinol were obtained from Phytolab (Vestenbergsgreuth, Germany). Cells P3X63Ag8.653 were purchased from ATCC (ATCC® CRL-1580). Fractions were concentrated in a Büchi R100 rotavap. Solvents used in this study were distilled prior to use and dried over appropriate drying agents. NMR spectra were recorded on a Bruker AVANCE III $500 \mathrm{MHz}$ spectrometer, Bruker Biospin GmbH, Rheinstetten, Germany, and TMS were used as an internal standard.

Gas chromatography-Mass Spectrometry (GC-MS) analysis was performed on an Agilent 7890, California, USA, with an Agilent 5975 mass detector, using a column HP5-MS $30 \mathrm{~m} \times 0.25 \mathrm{~mm}$ silica and a $0.25 \mu \mathrm{m}$ film thickness. Spectra were compared with standard mass spectra in addition to the NIST07 database (NIST 2008, National Institute of Standards and Technology).

\section{Plant material and extraction}

Stemwood, branch and knots of A. araucana were collected in May 2018 on Nahuelbuta range (Biobío Region, 3741'43.56'’S 7307'49.34''W). Samples were identified by the botanist Dr. Roberto Rodríguez from the University of Concepcion. $100 \mathrm{~g}$ of stemwood, branch and knots of A. araucana were chopped, dried at $40{ }^{\circ} \mathrm{C}$ for $8 \mathrm{~h}$, and milled to $1-3 \mathrm{~mm}$, and then they were continuously extracted on a Soxhlet. Briefly, in a $250 \mathrm{~mL}$ Soxhlet, $2-5 \mathrm{~g}$ of sample was placed in a cellulose thimble with acetone $(250 \mathrm{~mL})$ and refluxed for $12 \mathrm{~h}$, then the organic layer was filtered through a GV Durapore filter $(0.22 \mu \mathrm{m}$ pore size, 13 $\mathrm{mm}$ diameter, Millipore, Bedford, MA, USA) and evaporated in vacuo, giving a total organic extract, which was weighted and kept frozen at $-20^{\circ} \mathrm{C}$ until use. 
Additionally, a branch of A. araucana was processed according to Figure 3A. Briefly, the branch of $1,20 \mathrm{~m}$ and around $10 \mathrm{~cm}$ diameter, was cut in 22 slices of $4 \mathrm{~mm}$ width, using an electric saw, previously cleaned with acetone. The wood powder of each slice was carefully gathered and extracted in Soxhlet, as previously described.

\section{Quantification of lignans by HPLC}

Quantification of lignans were by HPLC (Young Lin, Anyang, South Korea) with PDA detector (PDA YL9160), using a reverse phase column Kinetex ${ }^{\circledR} 2.6$ $\mu \mathrm{m} \mathrm{C} 18100 \AA, 150 \times 4.6 \mathrm{~mm}$. The mobile phase was: A) water with $0.1 \%$ formic acid and Phase B) acetonitrile. A gradient program was used as follow: 0-42 min $15-45 \%$ B, $42-45 \min 45-100 \%$ B, $45-50 \min 100 \%$ B, 50-60 min 100-15\% B. The flux was constant to $0.4 \mathrm{~mL} \mathrm{~min}^{-1}$, at $25^{\circ} \mathrm{C}$ and injections were of $4 \mu \mathrm{L}$. A calibration curve of eudesmin was measured at $280 \mathrm{~nm}$. The analytical parameters were calculated from the calibration curve, with $n=6: R^{2}=0.9972$, $\mathrm{LOD}=1.11 \mathrm{mg} \mathrm{L}^{-1}, \mathrm{LOQ}=3.72 \mathrm{mg} \mathrm{L}^{-1}$.

The lignans eudesmin, matairesinol, secoisolariciresinol and lariciresinol were identified according to retention time and molecular absorption spectra comparing to commercially available standards. Matairesinol, secoisolariciresinol and lariciresinol were quantified by extrapolation on the calibration curve of eudesmin, and they are expressed in terms of eudesmin content.

\section{Antioxidant activity against DPPH radical}

The antioxidant activity of the extract from the knotwood, stemwood and branch were evaluated using the DPPH (2,2-diphenyl-1-picrylhydrazil) radical reduction test according to the methodology proposed by Hatano et al. [11]. Concentrations of $100,50,25$, and $10 \mu \mathrm{g} \mathrm{mL}^{-1}$ were prepared from the total extracts in ethanol. An aliquot of $150 \mu \mathrm{L}$ was taken from each sample and mixed with an equal volume of DPPH solution $(60 \mathrm{mM})$.

The resulting solution was vortexed and the absorbance was measured against the target on Biotek@ ELX800 microplate reader at a wavelength of $520 \mathrm{~nm}$. The results were expressed as the percentage of antioxidant activity and compared with the TROLOX reference standard (6-hydroxy-2,5,7,8-tetramethylcroman-2carboxylic acid) as a control [11]. The DPPH radical reduction activity was calculated with the following formula:

$\mathrm{DPPH}(\%)=(\mathrm{Abc}-\mathrm{Abs}) / \mathrm{Abc} \times 100$

Where Abc is the absorbance of control (ethanol). Abs is the absorbance of the sample, lectures at $520 \mathrm{~nm}$. Data is reported as IC50 DPPH radical inhibition.

\section{TLC and bioautography with DPPH}

Extracts of stemwood, branchwood and knotwood in concentrations of $12 \mathrm{mg}$ $\mathrm{mL}^{-1}$ in acetone were seeded on a TLC and eluted using dichloromethane-ethanol 93:7 v/v. Then, the TLC plate was sprayed with a solution of $0.5 \% \mathrm{w} / \mathrm{v}$ of DPPH in ethanol; after $30 \mathrm{~min}$ the plate was examined to the daylight, according to the method of Dewanjee et al. [12]. Free-radical scavengers appear as cream/yellow spots against a purple background.

\section{Cytotoxic activity against cancer cells}

\section{Cell culture}

Murine myeloma cells (P3X) and human neuroblast cells (SH-SY5Y) were used to investigate cytotoxicity of extract from stemwood, branchwood, knotwood and isolated compound eudesmin. SH-SY5Y cells lines were cultured in DMEM-F12 (Dulbecco's Modified Eagle's Medium - Nutrient Mixture F-12) culture medium while P3X RPMI 1640, either complemented with $10 \%$ fetal bovine serum (FBS), $1 \%$ glutamine and $1 \%$ penicillin/streptomycin, maintained at $37{ }^{\circ} \mathrm{C}$, with $5 \% \mathrm{CO} 2$ flow, in humidified incubator. Cells were diluited three times per week to mainten them in a normal condition of growth and collected for the antiproliferative assays in the exponential phase of growth.

\section{Cytotoxicity assay}

Cell viability was investigate using the 3-(4,5-dimethylthiazol-2-yl)-2,5diphenyltetrazolium bromide (MTT) assay, a colorimetric method to visualize the functionality of mitochondrial succinate dehydrogenase (correlated with cell metabolic activity) by reduction of MTT into formazan crystals, as reported by
Garzoli and colleagues [13]. Briefly, SH-SY5Y (2x10 4 cells/well) and P3X $\left(2 \times 10^{4}\right.$ cells/well) cells were seeded in 96-well plates and treated with seven 2 fold dilutions $\left(1000,500,250,125,62.5,31.2\right.$, and $\left.15.6 \mu \mathrm{g} \mathrm{mL}^{-1}\right)$ with stemwood, branchwood, knotwood extracts and eudesmin in triplicate for 24h.

As negative control, cells without treatment were added. Following treating incubation time, media was carefully removed and MTT solution $\left(0.5 \mathrm{mg} \mathrm{mL}^{-1}\right)$ was added each well and leave to react for $3 \mathrm{~h}$ at $37^{\circ} \mathrm{C}$ to allow formazan crystals formation. After this incubation time, cells were centrifuged in a plate centrifuge, the medium was removed and an organic solvent (dimethyl sulfoxide) was added to completely dissolvejthe formazan crystals. After $15^{\prime}$ plates were read by a microplate reader (SunRise, TECAN, Inc, USA) at $595 \mathrm{~nm}$ to evaluate the number of viable cells, directly correlated with the amount of colour produced. The $\%$ of viability was calculated as follow:

$$
\% \text { viability }=(1-(\mathrm{S} \lambda / \mathrm{C} \lambda)) \times 100
$$

$\mathrm{S} \lambda$ : absorption of wells treated with the stemwood, branchwood, knotwood extracts and eudesmin;

$\mathrm{C} \lambda$ : absorption of untreated cells.

The relation between viability and samples concentration is plotted to obtain a survival curve of tumor cell lines. The effective concentration at 50\% (IC50) was estimated from graphs of the dose response curve for each concentration using GraphPad Prism software (version 8.4.2).

\section{RESULTS AND DISCUSSION}

Identification of lignans from stemwood, branchwood, knotwood of $A$. araucana

The extraction of $100 \mathrm{~g}$ of knotwood of Araucaria with acetone gave $26.1 \mathrm{~g}$ of total extract, which was concentrated by slow evaporation at $4{ }^{\circ} \mathrm{C}$, precipitating $1.4 \mathrm{~g}$ of colorless crystals identified as eudesmin, Figure 1.
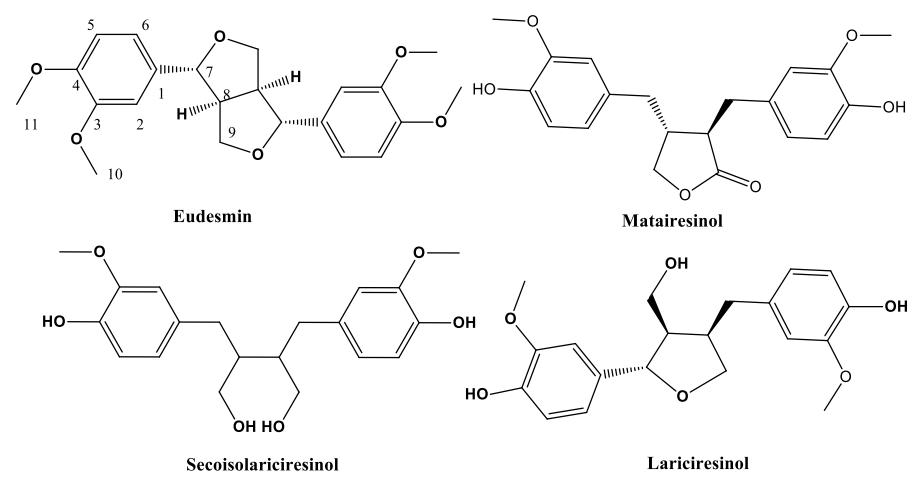

Figure 1. Structure of lignans identified form Araucaria araucana knotwood.

The structure of eudesmin was determinate by RMN analysis. The results agree with data reported in literature $[14,15]$. Eudesmin or $(1 \mathrm{R}, 3 \mathrm{aS}, 4 \mathrm{R}, 6 \mathrm{aS})-1,4$ bis(3,4-dimethoxyphenyl) hexahydrofuro [3,4-c] furan. ${ }^{1} \mathrm{H}$ NMR $(600 \mathrm{MHz}$, $\left.\mathrm{CCl}_{3} \mathrm{D}\right) \delta: 7.02(\mathrm{~d}, \mathrm{~J}=1.0 \mathrm{~Hz}, 1 \mathrm{H}, \mathrm{H}-2), 6.92(\mathrm{~d}, \mathrm{~J}=8.5 \mathrm{~Hz}, 1 \mathrm{H}, \mathrm{H}-5), 6.94(\mathrm{dd}$, $\mathrm{J}=2.0,6.0 \mathrm{~Hz}, 1 \mathrm{H}, \mathrm{H}-6), 4.73(\mathrm{~d}, \mathrm{~J}=4.5 \mathrm{~Hz}, 1 \mathrm{H}, \mathrm{H}-7), 4.78(\mathrm{~m}, 1 \mathrm{H}, \mathrm{H}-9), 4.28$ (m, 1H, H-9), 3.92 (s, 3H, C-11), 3.90 (s, 3H, C-10), 3.12 (m, 1H, H-7). Mass: 386. Formula: $\mathrm{C}_{22} \mathrm{H}_{26} \mathrm{O}_{6}$.

Quantification of extractables and lignans from stemwood, branchwood and knotwood of A. araucana

The extraction, with acetone, of a representative sample of milled wood collected from three tissues of A. araucana gave the following yields: Stemwood $0.9 \% \mathrm{w} / \mathrm{w}$, branchwood $1.2 \% \mathrm{w} / \mathrm{w}$, knotwood $26.1 \% \mathrm{w} / \mathrm{w}$. These results showed big differences in the concentration of extractables in the tissues of A. araucana, suggesting that the preservation of knots of Araucaria in the forest, without decomposition, could be due to a high amount of extractables in this tissue, which is 29 -folds higher than in stemwood.

Four lignans were quantified by HPLC in stemwood, branchwood and knotwood of A. araucana, Figure 2, Table 1. 


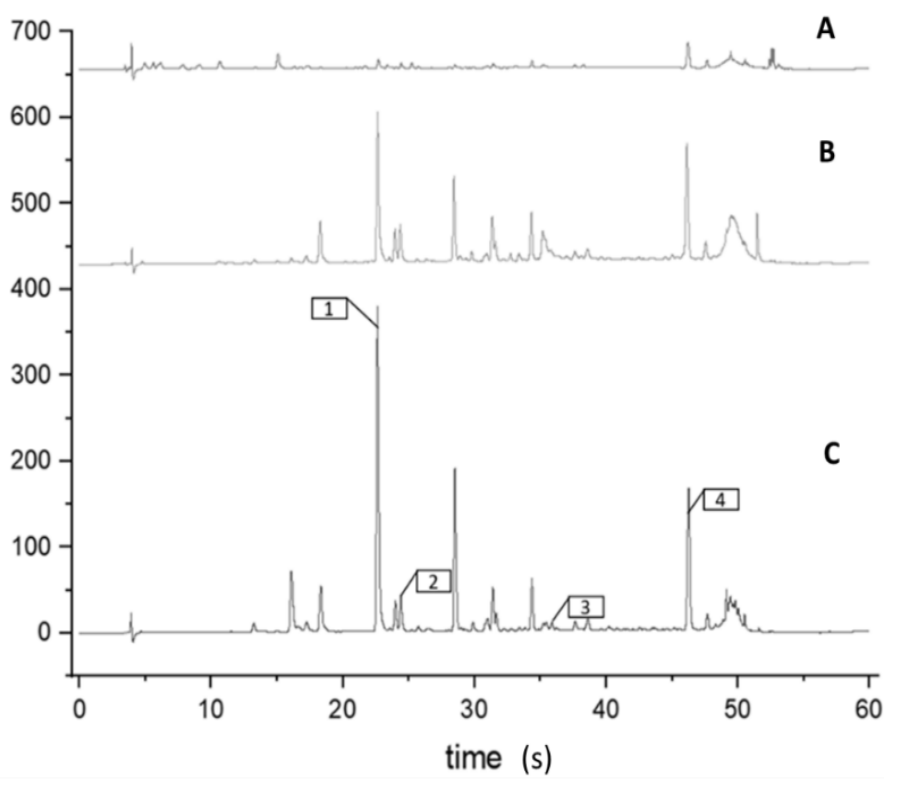

Figure 2. Representative HPLC-PDA chromatograms of total extracts at same concentration (10 $\mathrm{m} \mathrm{mL}^{-1}$ ) of A) stemwood, B) branchwood and C) knotwood. The peaks of the standards of secoisolariciresinol 1, lariciresinol 2, matairesinol 3 , eudesmin 4 , are given in figure $\mathrm{C}$.

Table 1. Concentration of four lignans in tissues of Araucaria araucana.

\begin{tabular}{|c|c|c|c|c|}
\hline Tissue & $\begin{array}{c}\text { Secoisolariciresinol } \\
\mathbf{m g ~ g}^{-1}\end{array}$ & $\begin{array}{c}\text { Eudesmin } \\
\mathbf{m g ~ g}^{-1}\end{array}$ & $\begin{array}{c}\text { Lariciresinol } \\
\mathbf{m g ~ g}^{-1}\end{array}$ & $\begin{array}{c}\text { Matairesinol } \\
\mathbf{m g ~ g}^{-1}\end{array}$ \\
\hline Stemwood & 0.03 & 0.10 & 0.02 & 0.02 \\
\hline Branchwood & 1.50 & 1.43 & 0.24 & 0.42 \\
\hline Knotwood & 45.77 & 22.68 & 4.57 & 1.19 \\
\hline
\end{tabular}

The chromatogram in the Figure $2 \mathrm{C}$, shows at least, 12 compounds in the knotwood extract, in spite that in this study, only four of them were identified as eudesmin, matairesinol, secoisolariciresinol and lariciresinol ( Figure 1), which were quantified, in terms of eudesmin. The compound secoisolariciresinol is the lignan present in higher concentration in stemwood, branchwood and knotwood of Araucaria. In the knots its concentration is remarkable with 30.5-Folds and 1526-Folds higher than in stemwood and branchwood, respectively. The second lignan in major concentration is eudesmin, followed by lariciresinol and matairesinol, showing the same pattern as secoisolariciresinol.

Quantification of extractables and lignans from different parts of a branch of A. araucana

The quantification of extractables and lignans were measured in all length of a branch of A. araucana of $1.20 \mathrm{~m}$ length, Figure 3A. The branch was cut in 22 slices from left (part of knot in red) to the right (branchwood in green color), as it is shown in Figure 3B. Extractables obtained from milled wood of each cut were quantified by gravimetry and summarized in Figure 3C.

Results showed a higher concentration of extractables in the samples, which include the knot part (left side), than in samples of branchwood (right side). Figure 3D summarizes the concentration of four lignans; eudesmin, matairesinol, secoisolariciresinol and lariciresinol, determinate by HPLC. These results agree with the concentration of extractives showed in Table 1, where higher amounts of lignans were found in the knot.

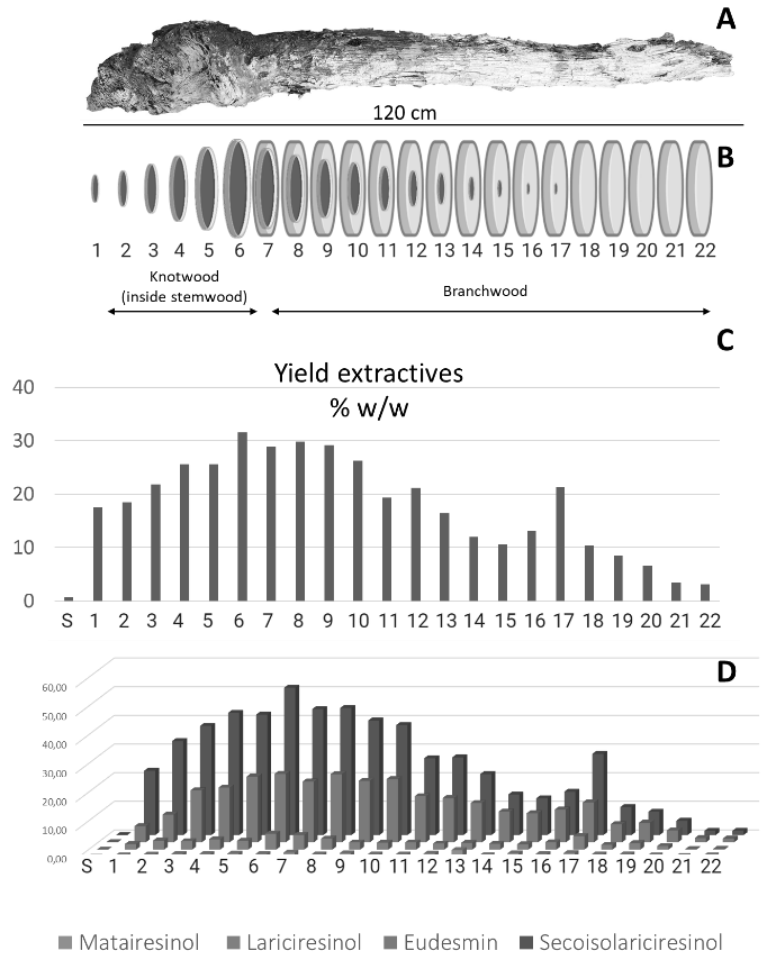

Figure 3. Quantification of extractables and pure lignans in different parts of a branch of A. araucana. A) Branch of A. araucana including the knot in left side. B) Scheme of 22 wood samples cut from the branch of $A$. araucana. C) Concentration of extractables in \%w/w from each sample. D) Graph of quantification of eudesmin, matairesinol, secoisolariciresinol and lariciresinol in the 22 wood samples from 3B. S Stemwood. 3B created with BioRender.com.

The concentration of lignans vary long a branch of A. araucana as was shown in Figure 3D. The results of each sample are given in Table 2, Where is it shown the higher the concentration of each lignans, the close is to the knots between samples 5 to 7 , and decreases to the right side of the branch moving away to the knot.

Table 2. Quantification of lignans along a branch of A. araucana.

\begin{tabular}{|c|c|c|c|c|}
\hline Sample & $\begin{array}{c}\text { Matairesinol } \\
\text { mg g-1 }\end{array}$ & $\begin{array}{c}\text { Lariciresinol } \\
\text { mg g-1 }\end{array}$ & $\begin{array}{c}\text { Eudesmin } \\
\text { mg g-1 }\end{array}$ & $\begin{array}{c}\text { Secoisolariciresinol } \\
\text { mg g-1 }\end{array}$ \\
\hline 1 & 0.56 & 1.94 & 5.66 & 22.44 \\
\hline 2 & 0.82 & 3.15 & 9.68 & 32.79 \\
\hline 3 & 1.02 & 2.94 & 18.16 & 38.07 \\
\hline 4 & 1.01 & 3.60 & 19.10 & 42.62 \\
\hline 5 & 1.12 & 3.07 & 22.93 & 42.01 \\
\hline 6 & 0.99 & 5.54 & 23.88 & 51.38 \\
\hline 7 & 1.47 & 5.09 & 21.22 & 43.93 \\
\hline 8 & 0.89 & 3.83 & 23.77 & 44.33 \\
\hline 9 & 1.26 & 2.52 & 21.45 & 39.94 \\
\hline 10 & 0.87 & 2.44 & 22.09 & 38.36 \\
\hline 11 & 0.86 & 2.52 & 16.10 & 26.79 \\
\hline 12 & 1.13 & 2.12 & 15.45 & 27.10 \\
\hline 13 & 2.38 & 2.34 & 13.74 & 21.29 \\
\hline 14 & 0.58 & 2.03 & 10.73 & 14.15 \\
\hline 15 & 1.27 & 1.87 & 10.15 & 12.83 \\
\hline 16 & 1.00 & 2.57 & 11.45 & 15.13 \\
\hline 17 & 1.34 & 4.73 & 13.94 & 28.32 \\
\hline 18 & 0.88 & 1.67 & 6.35 & 9.78 \\
\hline 19 & 0.90 & 2.27 & 6.83 & 8.15 \\
\hline 20 & 0.56 & 1.27 & 4.16 & 5.03 \\
\hline 21 & 0.28 & 0.20 & 1.51 & 1.49 \\
\hline 22 & 0.56 & 0.28 & 1.35 & 1.51 \\
\hline & & & & \\
\hline
\end{tabular}

Results expressed dry basis. 
Antioxidant and cytotoxic activity of extractables from stemwood, branchwood and knotwood of A. araucana.

The antioxidant capacity of extracts was visualized by bioautography, Figure 4. TLC to left side was stained with DPPH and yellow spots showed antioxidants compounds. According to the previous results, the major number of polyphenols are in samples of knotwood, branchwood, than that in stemwood, which also showed the higher activity in terms of DPPH reduction with an IC50 10.18, 30.49 and $72.17 \mu \mathrm{g} \mathrm{mL}^{-1}$ respectively, Table 3. In the Figure 4, knotwood (right side), the position of each lignan was pointed out. Eudesmin is the less polar compound with higher retention factor on silica gel TLC, followed by matairesinol, lariciresinol and secoisolariciresinol. In the DPPH radical reduction test by bioautography, eudesmin showed no activity, where the band corresponding to eudesmin did not give positive coloration, as well as by spectrophotometry, Table 3. These results are consistent with the literature [16].
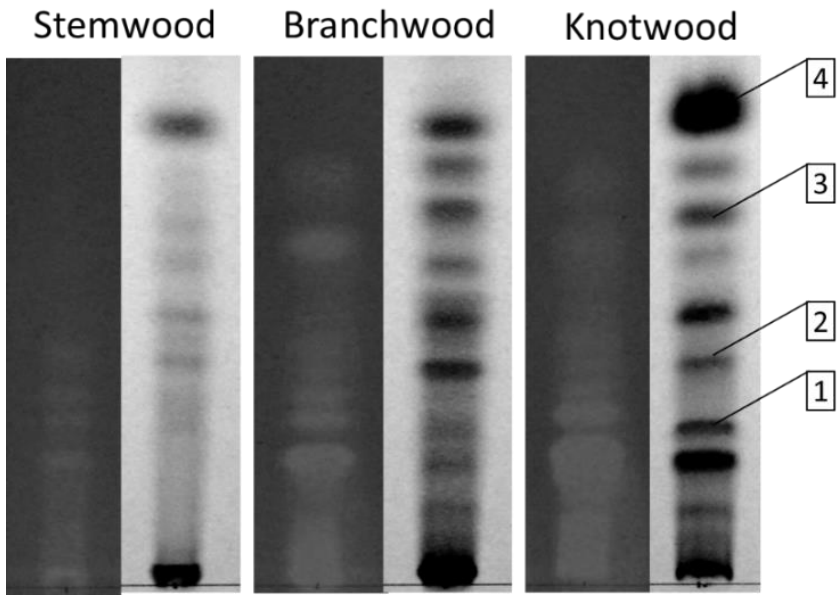

Figure 4: TLC analysis followed by bioautography DPPH activity. The plates were revelated with DPPH reagent (left) and a duplicate was revelated with sulfuric acid/ethanol (right). secoisolariciresinol 1, lariciresinol 2, matairesinol 3 , eudesmin 4 .

The cytotoxic activity results of the extracts and eudesmin are given in the Table 3 . The extracts display moderate activity against both neuroblastoma and myeloma cancer cell lines. While eudesmin did not show activity over $200 \mu \mathrm{g}$ $\mathrm{mL}^{-1}$.

Table 3. Activity of the total extract, in acetone, of knotwood, branch and stemwood of A. araucana in DPPH radical reduction analysis and cytotoxic assays in SHSY5Y neuroblastoma and P3X myeloma cell lines, $\mathrm{n}=3$.

\begin{tabular}{|c|c|c|c|}
\hline Treatment & $\begin{array}{c}\text { DPPH } \\
\text { IC50 }\left(\boldsymbol{\mu g} \mathbf{~ m L}^{-\mathbf{1}}\right)\end{array}$ & $\begin{array}{c}\text { SH-SY5Y } \\
\mathbf{I C 5 0}\left(\boldsymbol{\mu g} \mathbf{~ m L}^{-\mathbf{1}}\right)\end{array}$ & $\begin{array}{c}\text { P3X } \\
\mathbf{I C 5 0}\left(\boldsymbol{\mu g} \mathbf{~ m L}^{-\mathbf{1}}\right)\end{array}$ \\
\hline Knotwood & 10.18 & 71.52 & 67.9 \\
\hline Branch & 30.49 & 83.4 & 79.13 \\
\hline Stemwood & 72.17 & 145.52 & 120.2 \\
\hline Eudesmin & n.a. & $>200$ & $>500$ \\
\hline Trolox & 5.58 & - & - \\
\hline
\end{tabular}

DPPH is expressed in amount of extract needed to reduce $50 \%$ of the DPPH radical(IC50). n.a. no activity.

\section{Possible role of $A$. araucaria wood extractables}

Based on the results obtained, the difference in lignan concentration between stemwood and knotwood from A. araucana is notorious. This accumulation of phenolic compounds in tree knots has been studied in other gymnosperms from northern hemisphere, whose results suggest that the presence of phenols such as lignans or stilbenes would be exerting a chemical barrier as free radical scavengers, properties that counteract the attack of xylophagous fungi, such as brown rot, which generate free radicals to gain access to the cellulose[2].
Another interesting role of lignans from knotwoods on the soil surface is that they could be exerting an allelopatic effect, because some of these compounds, like lariciresinol and secoisolariciresinol, are highly phytotoxic, therefore, they would be exerting a local ecological effect that needs further study[17].

\section{CONCLUSION}

Lignans are an important family of bioactive compounds with antifungal, antibacterial and insecticidal effects, which are used by conifers as a chemical defense; moreover, they have also shown pharmacological properties as anticarcinogens, and as a food supplement because of their beneficial effects on human health [18-20]. For instance, extracts of lignan-rich Picea abies knots are added to the winemaking process to improve its properties enhancing its quality $[21,22]$. The lignans secoisolariciresinol, eudesmin, lariciresinol and pinoresinol have already been reported in the heartwood of native Chilean species such as $A$. araucana, Fitzroya cupressoides, and Austrocedrus chilensis [18, 23, 24] Chemical investigation on extracts of stemwood, branchwood and knotwood from Araucaria were carried out. Our results, in Araucaria araucana, evidenced the presence of secoisolariciresinol, lariciresinol, matairesinol and eudesmin in higher concentration in the knots of Araucaria, than in stemwood. The biological reasons for this high chemical concentration in knots have not been fully clarified, because physiologically, the secondary metabolites of extractables are synthesized in the sapwood and transport to the heartwood, activity that is enhanced when the tree is damage, but how they move and accumulate in knots is not well understood [25]. We suggest that knots with a high concentration of extractable rich in lignans are part of a chemical protection mechanism. The union between the trunk and the branches supports important mechanical loads due to the weight of the branches and environmental factors such as wind, snow and precipitation that induce strong mechanical stress. Self-pruning of branches after death could also be the origin of the entry of pathogens and oxygen that could damage the living tissues of the stem. Consequently, the knots must be both mechanically and resistant to xylophage predation [2]. The knots of Araucaria were used for a long time as wood to burn and recently as material for artisans. However, it has a potential use as a source of lignans, specially eudesmin, which crystallize in organic solvents at low temperature, facilitation its purification. Extracts of stemwood, branchwood, knotwood, and all isolated compounds were evaluated for their cytotoxicity and antioxidant bioassays. In the cytotoxic analysis of eudesmin, it did not give positive cytotoxic activity in SHSY5Y and P3X cells., In comparison to other studies in PC3 (Prostate carcinoma), MCF (Breast carcinoma), PA1 (Ovary carcinoma), DLD1 (Colon carcinoma), or M4Beu (Malignant melanoma) [26], that showed that eudesmin possesses significant antitumor effects on lung cancer A549 (IC50 $18.3 \mathrm{uM}$ ) via to induction of mitochondria-mediated apoptosis [27], as well as in nasopharyngeal carcinoma cells eudesmin inhibited cell viability and induced apoptosis of NPC cells [28]. However, the cytotoxic activity is not fully understanding, could be suggested that eudesmin is high specific against some particular cancer cell lines; this deserves more in-depth studies and could become a potential cancer-fighting drug.

\section{AKNOWLEDGMENTS}

This work was funded by the National Agency for Research and Development (ANID -Chile) by the scholarship program "Doctorado Becas Chile" 21151154, Conicyt PIA/Apoyo CCTE AFB170007. We thanks to Héctor Sáez and Mario Cornejo from Los Alamos, Arauco for his assistance in the collection of the samples, and to Professor Roberto Rodríguez for the botanical characterization of samples. We also thank Dr. Carola Vergara and Francisca Narvaez for providing lignan standards.

Authors declare no conflicts of interest.

\section{REFERENCES}

1. Vermerris, W., Nicholson, R.: Phenolic Compound Biochemistry. Springer, Dordrecht; London (2008)

2. Kebbi-Benkeder, Z., Colin, F., Dumarçay, S., Gérardin, P.: Quantification and characterization of knotwood extractives of 12 European softwood and hardwood species. Ann. For. Sci. 72, 277-284 (2015) https://doi.org/10.1007/s13595-014-0428-7

3. Valette, N., Perrot, T., Sormani, R., Gelhaye, E., Morel-Rouhier, M. Antifungal activities of wood extractives. Fungal Biol. Rev. 31, 113-123 (2017). https://doi.org/10.1016/j.fbr.2017.01.002 
4. Trapp, S., Croteau, R.: DEFENSIVE RESIN BIOSYNTHESIS IN CONIFERS. Annu. Rev. Plant Physiol. Plant Mol. Biol. 52, 689-724 (2001). https://doi.org/10.1146/annurev.arplant.52.1.689

5. Kebbi-Benkeder, Z., Dumarçay, S., Touahri, N., Manso, R., Gérardin, P., Colin, F.: Les noeuds: un bois méconnu et une source importante de composés extractibles. Biol. Écologie. (2016)

6. Willfor, S., Nisula, L., Hemming, J., Reunanen, M., Holmbom, B.: Bioactive phenolic substances in industrially important tree species. Part 1: Knots and stemwood of different spruce species. Holzforschung. 58, (2004). https://doi.org/10.1515/HF.2004.052

7. Belt, T., Hänninen, T., Rautkari, L.: Antioxidant activity of Scots pine heartwood and knot extractives and implications for resistance to brown rot. Holzforschung. 71, (2017). https://doi.org/10.1515/hf-2016-0232

8. Anderegg, R.J., Rowe, J.W.: Lignans, the Major Component of Resin from Araucaria angustifolia Knots. Holzforschung. 28, 171-175 (1974) https://doi.org/10.1515/hfsg.1974.28.5.171

9. Ohashi, H., Kawai, S., Sakurai, Y., Yasue, M.: Norlignan from the knot resin of Araucaria angustifolia. Phytochemistry. 31, 1371-1373 (1992). https://doi.org/10.1016/0031-9422(92)80293-N

10. Willför, S.M., Smeds, A.I., Holmbom, B.R.: Chromatographic analysis of lignans. J. Chromatogr. A. 1112, 64-77 (2006) https://doi.org/10.1016/j.chroma.2005.11.054

11. Hatano, T., Edamtsu, R., Hiramatsu, M., Mori, A., Fujita, Y., Yasuhara, T., Yoshida, T., Okuda, T.: Effects of the Interaction of Tannins with Co-existing Substances. VI. : Effects of Tannins and Related Polyphenols on Superoxide Anion Radical, and on 1,1-Diphenyl-2-picrylhydrazyl Radical. Chem Pharm Bull. 37, 2016-2021 (1989)

12. Dewanjee, S., Gangopadhyay, M., Bhattacharya, N., Khanra, R., Dua, T.K.: Bioautography and its scope in the field of natural product chemistry. J. Pharm. Anal. 5, 75-84 (2015). https://doi.org/10.1016/j.jpha.2014.06.002

13. Garzoli, S., Masci, V.L., Ovidi, E., Turchetti, G., Zago, D., Tiezzi, A.: Chemical Investigation of a Biologically Active Schinus molle L. Leaf Extract. J. Anal. Methods Chem. 2019, 1-6 (2019). https://doi.org/10.1155/2019/8391263

14. Yamamoto, S., Otto, A., Simoneit, B.R.T.: Lignans in resin of Araucaria angustifolia by gas chromatography/mass spectrometry. J. Mass Spectrom. 39, 1337-1347 (2004). https://doi.org/10.1002/jms.726

15. Yamamoto, S., Cox, R.E., Simoneit, B.R.: Gas Chromatography/Mass Spectrometry of the Lignans in Resin of Callitris preissii. J. Mass Spectrom. Soc. Jpn. 58, 195-209 (2010)

16. Parhoodeh, P., Rahmani, M., Hashim, N.M., Sukari, M.A., Cheng Lian, G.E.: Lignans and Other Constituents from Aerial Parts of Haplophyllum Villosum. Molecules. 16, 2268-2273 (2011). https://doi.org/10.3390/molecules16032268

17. DellaGreca, M., Zuppolini, S., Zarrelli, A.: Isolation of lignans as seed germination and plant growth inhibitors from Mediterranean plants and chemical synthesis of some analogues. Phytochem. Rev. 12, 717-731 (2013). https://doi.org/10.1007/s11101-013-9311-7
18. Céspedes A, C.L., Avila, J.G., Marin, J.C., Domínguez L, M., Torres, P., Aranda, E.: Chapter 1 Natural compounds as antioxidant and molting inhibitors can play a role as a model for search of new botanical pesticides. In: Carpinella, M.R. and M.C. (ed.) Advances in Phytomedicine. pp. 1-27. Elsevier (2006)

19. Landete, J.M.: Plant and mammalian lignans: A review of source, intake, metabolism, intestinal bacteria and health. Food Res. Int. 46, 410-424 (2012). https://doi.org/10.1016/j.foodres.2011.12.023

20. Yatkin, E., Polari, L., Laajala, T.D., Smeds, A., Eckerman, C., Holmbom, B., Saarinen, N.M., Aittokallio, T., Mäkelä, S.I.: Novel Lignan and Stilbenoid Mixture Shows Anticarcinogenic Efficacy in Preclinical PC-3M-luc2 Prostate Cancer Model. PLoS ONE. 9, e93764 (2014). https://doi.org/10.1371/journal.pone.0093764

21. Balík, J., Híc, P., Kulichová, J., Novotná, P., Tříska, J., Vrchotová, N., Strohalm, J., Lefnerová, D., Houška, M.: Musts with Increased Lignan Content Through Addition of Lignan Extracts. Food Bioprocess Technol. 10, 1367-1373 (2017). https://doi.org/10.1007/s11947-017-1911-6

22. Josef, B., Pavel, H., Jana, K., Pavla, N., Jan, T., Naděžda, V., Jan, S., Milan, H.: Wines with Increased Lignan Content by the Addition of Lignan Extracts. Czech J. Food Sci. 34, 439-444 (2016). https://doi.org/10.17221/575/2015CJFS

23. Calvo-Flores, F.G., Dobado Jiménez, J.A., Garcia, J.I., Martín-Martínez, F.J.: Lignin and lignans as renewable raw materials: chemistry, technology and applications. John Wiley and Sons, Inc, Chichester, West Sussex, United Kingdom (2015)

24. Donoso, C.A., Becerra, J., Bittner, M., Elissetche, J.P., Freer, J., Mendoza, R., Sterner, O., Silva, M.: Allelochemicals and natural durability in Chilean Cupressaceae heartwoods. Allelopathy J. 21, 119-132 (2008)

25. Kebbi-Benkeder, Z., Manso, R., Gérardin, P., Dumarçay, S., Chopard, B. Colin, F.: Knot extractives: a model for analysing the eco-physiological factors that control the within and between-tree variability. Trees. (2017). https://doi.org/10.1007/s00468-017-1573-z

26. Lim, S., Grassi, J., Akhmedjanova, V., Debiton, E., Balansard, G., Beliveau, R., Barthomeuf, C.: Reversal of P-Glycoprotein-Mediated Drug Efflux by Eudesmin from Haplophyllum perforatum and Cytotoxicity Pattern versus Diphyllin, Podophyllotoxin and Etoposide. Planta Med. 73, 1563-1567 (2007). https://doi.org/10.1055/s-2007-993754

27. Jiang, L.-L., Sun, B.-R., Zheng, C., Yang, G.-L.: The antitumour effects of eudesmin on lung cancer by inducing apoptosis via mitochondria-mediated pathway in the tumour cells. Pharm. Biol. 55, 2259-2263 (2017). https://doi.org/10.1080/13880209.2017.1401647

28. Yu, M., Li, Y., Li, M., Lu, D.: Eudesmin exerts antitumor effects by downregulating EZH2 expression in nasopharyngeal carcinoma cells. Chem. Biol. Interact. 307, 51-57 (2019). https://doi.org/10.1016/j.cbi.2019.04.028 